ENVIRONMENTAL SCIENCE

\title{
Arsenic Contamination in Ground Water at Deoghar (Jharkhand)
}

\section{Ashok Kumar}

Department of Botany, A.S. College, S.K.M. University, Deoghar-814112, Dumka, Jharkhand, India

Corresponding author: drashokkumarbotany@gmail.com (ORCID ID: 0000-0003-4360-9329)

Paper No. 799

Received: 16-06-2019

Revised: $13-10-2019$

Accepted: 27-11-2019

\begin{abstract}
Arsenic contamination in ground water is one of the major natural calamities of the world to the mankind. In the present study, altogether 20 water samples from 20 different tube wells of the house hold of Deoghar town were collected and analyzed on the spot with the help of arsenic test kit (color comparison method, [semi quantitative]). Final confirmation was made using atomic absorption spectrophotometer. The lowest average value $0.444 \mathrm{ppm}$ was recorded in the south part and the highest average value 1.2 pm was recorded in the north part of the Deoghar town.

Highlights

(0 The underground water of Deoghar(Jharkhand) contains arsenic level beyond permissible limit of WHO.

( It may lead hazardous diseases to the people.
\end{abstract}

Keywords: Arsenic contamination, Ground water, anthropogenic activity, acute toxicity, Hazardous disease

Arsenic contamination in drinking water is one of the vital natural calamities of the world to the human beings, reported in several countries such as Argentina, Bangladesh, Chile, China, India, Mexico and USA.. The chief source of its introduction into soil and ground water is the dissolution of rocky minerals and ores followed by subsequent leaching as well as runoff and can also be introduced into soil and ground water from anthropogenic activities. Arsenic, an extremely toxic in its inorganic form, is omnipresence element found in various compounds throughout the earth's crust. In Bangladesh large number of tube wells have been reported contaminated with arsenic beyond the permissible limit of world Health Organization (WHO)(Rahman et al. 1998, 1999; Ahmad et al. 1997, 1999; Dhar et al. 1997; Bishwas et al. 1998; Tondel et al. 1999; Rahman and Axelson, 2001; Choudhary et al. 2000). In India, for the first time ground water contamination of arsenic was observed in the West Bengal in 1980s by Haque et al. (2003) and Acharyya et al. (1999). Recently the problems have also been found in Bihar and Uttar Pradesh. Ghosh et al. (2007, 2009), Saha et al. (2009) and Singh et al. (2014) reported arsenic poisoning in ground water in 16 district of Bihar. A detailed study in the Sahibganj district of Jharkhand state in the middle Ganga plain was carried out to determine the severity of groundwater arsenic contamination and related adverse health hazards due to chronic arsenic exposure (Bishwajit Nayak et al. 2008).

Keeping in view the scarce and meagre research activities on groundwater arsenic contamination ,hazardous to human beings of Deoghar town where lakhs of pilgrims come to offer their Ganga jal to Dwadash Jyotirling specially during shrawan month, the present investigation has been undertaken to assess the condition of ground water extracted through tube wells and used for drinking purposes by inhabitants of this area. 


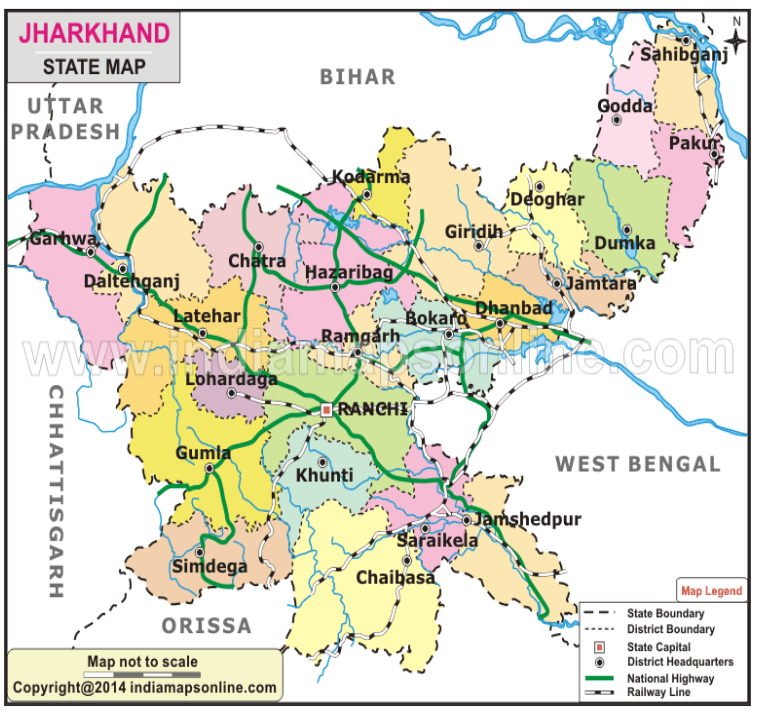

Map 1: Jharkhand state

\section{Study Area}

Deoghar is one of the $24^{\text {th }}$ district of Jharkhand state. It is situated in between $24^{\circ} 03^{\prime}$ and $24^{\circ} 3^{\prime}$ north latitude and between $86^{\circ} 26^{\prime}$ and $87^{\circ} 04^{\prime}$ east longitude. It lies above 247 meter from sea level and extends over 119.70 sq. km hectare area. Deoghar is a municipal corporation constituting 36 wards. Total population of the corporation area is 203123 (2011 census).

\section{MATERIALS AND METHODS}

Firstly the Deoghar town was divided into four parts i.e. East, West, North and South. In each part of the town five spots (tube wells) were selected for sampling and for analysis of underground water. The water samples were collected in $500 \mathrm{ml}$. volume of polypropylene bottles which were cleaned and pretreated with $\mathrm{HCl}$. Altogether 20 water samples were collected from 20 different tube wells of the town. Collected water samples were analyzed on the spot utilizing arsenic test kit (color comparison

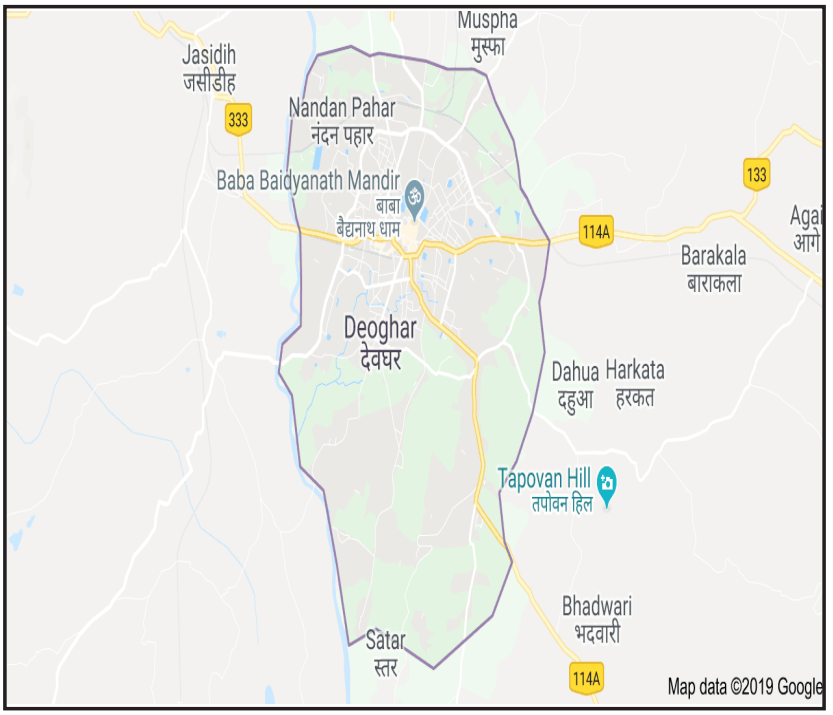

Map 2: Deoghar municipal area

method, semi quantitative). Final confirmation was made using atomic absorption spectrophotometer.

\section{RESULTS AND DISCUSSION}

In the present study, arsenic contamination in underground water of Deoghar was studied .The above findings indicate that the underground water of the East part of the town, the arsenic level was recorded from $0.09 \mathrm{ppm}$ to $1.02 \mathrm{ppm}$ with an average of $1.004 \mathrm{ppm}$ and in the West part the water contains $1.00 \mathrm{ppm}$ to $1.03 \mathrm{ppm}$ arsenic with 1.012 ppm average. In the North part the underground water bears $1.00 \mathrm{ppm}$ to $1.05 \mathrm{ppm}$ of arsenic with an average of $1.2 \mathrm{ppm}$ whereas the in the South part of the town arsenic level was recorded from 0.05 to $1.01 \mathrm{ppm}$ with an average of $0.444 \mathrm{ppm}$. Similar findings of arsenic level were recorded by A. Kumar and R.Kumar in the year 2016 while they were studying ground water contamination of arsenic in Buxar district of Bihar. Further Ghosh et al. (2009) and Singh et al. 2014 recorded similar

Table 1: Table Showing Arsenic Contimination in Ground Water at Deoghar

\begin{tabular}{llllllll}
\hline (A) East Part & & (B) West Part & (C) North Part & (D) South Part & \\
\hline Location & Conc. $(\mathbf{p p m})$ & Location & Conc. $(\mathbf{p p m})$ & Location & Conc.(ppm) & Location & Conc. (ppm) \\
\hline Baijnathpur & 1.02 & Belabagan & 1.03 & Jaruadih & 1.05 & Castairs Town & 1.00 \\
Karnibad & 1.00 & Indiranagar & 1.01 & Anand nagar & 1.00 & Bompas Town & 1.01 \\
Bandha & 1.01 & Civil Line & 1.00 & Rangamore & 1.00 & Baban bigha & 0.05 \\
Jhousaghari & 0.09 & Singhwa & 1.02 & Pokhnatila & 1.03 & Satar & 0.07 \\
Jagriti nagar & 1.00 & Barmasia & 1.00 & Salona & 1.02 & Kalyan pur & 0.09 \\
\hline Average & $\mathbf{1 . 0 0 4}$ & Average & $\mathbf{1 . 0 1 2}$ & Average & $\mathbf{1 . 0 2}$ & Average & $\mathbf{0 . 4 4 4}$ \\
\hline
\end{tabular}


level of arsenic in ground water. Smith et al. (2003), Ahmad et al. (2004) reported $50 \%$ of the hand pump water having arsenic level greater than $200 \mathrm{ppb}$ in West Bengal and Bangladesh respectively.

Long term exposure of inorganic arsenic beyond permissible limit through drinking water and food may lead so many hazardous diseases to the mankind.

\section{ACKNOWLEDGEMENTS}

Author is very much thankful to Dr. N.K. Singh; Rtd. Associate Professor Dept. of Botany; Deoghar College; Deoghar for his kind co-operation and sincere support.

\section{SUGGESTION}

As the arsenic is hazardous to human health and at certain locations at Deoghar its concentration is alarming and beyond the permissible limit of WHO. It is suggested that extensive investigation on arsenic contamination in groundwater at Deoghar is required.

\section{REFERENCES}

Acharyya, S.K., Choudhary, P., Lahiri, S., Raymahashay, B.C., Guha, S. and Bhomik, A. 1999. Arsenic poisioning in the Ganges delta. Nature, 401: 545.

Ahmad, S.A., Bandaranayake, D., Khan, W.A., Hadi, S.A., Uddin, G. and Halim, M.A. 1997. Arsenic contamination in ground water and arsenicosis in Bangladesh. Int. J. Environ. Health Res., 7(4): 271-276.

Ahmad, S.A., Sayeed, S.U., Hadi, S.A. and Faruquee, M.H. 1999. Arsenicosis in a village in Bangladesh. Int. J. Environ. Helth Res., 9(3): 187-196.

Bishwajeet, N. 2008. Ground water arsenic contamination in the Sahibganj district of Jharkhand state, India in the middle Ganga plain and adverse health effect. Toxicological and Environmental Chemistry, 90(4): 673-694.

Choudhary, U.K., Biswas, B.K., Choudhary, T.R., Samanta, G., Mandal, B.K., Basu, G.C., Chand, C.R., Lodh, D., Saha, K.C., Mukherjee, S.K., Roy, S., Kabir, S. Quamruzzaman, Q. and Chakraborty, D. 2000. Ground water arsenic contamination in Bangladesh and West Bengal. India. Environ. Helth Perspectives, 108(5): 393-397.
Dhar, R.K., Biswas, B.K., Samanta, G. and Mandal, B.K. 1997. Ground water arsenic calamity in Bangladesh. Curr. Sci., 73.

Ghosh, A.K., Singh, S.K., Bose, N., Sushant, K.S., Singh, A., Mishra, R., Roy, N.P. and Upadhyay, A. 2007. Study of arsenic contamination in ground water of Bihar (India) along the river Ganges: International Workshop on Arsenic Sourcing and Mobilization in Holocene Deltas. Department of Sience and Technology, Government of India, pp. 12-13.

Ghosh, A.K., Singh, S.K., Bose, N. and Singh, K. 2009. Arsenic hot spots detected in the state of Bihar (India) a serious health hazards for estimated human population of 5.5 lakh. In: Ramanathan A.L., Bhattacharya P., Kesri A.K., Bundschuh J., Chandrashekharam D., EDITORS. Assesment of Ground water Resources and Management. New Delhi: I.K. International Publishing House Pvt. Ltd. pp. 62-70.

Haque, R., Mazumdar, D.N., Samanta, S., Ghosh, N., Kalman, D. and Meera, M. 2003. Arsenic in drinking water and skin lesions: Dose- response data from West Bengal. India. Epidemiology, 14: 174-82.

Kumar, A., Rahman, M.S., Iqbal, M.A., Ali, M. Niraj, P.K., Anand, G., Abhinay, P.K. and Ghosh, A.K. 2016. Ground water arsenic contamination: A local survey in India. Int. J. Prev. Med., 9(7): 100.

Rahman, M. and Axelson, O. 2001. Arsenic ingestion and health effects in Bangladesh Epidemiological observation. In: Arsenic exposure and health Effects. edited by Chappell W.R. Abernathy C.O, Caldron R.L.C Elsevier Science B V 193-9.

Saha, D. 2009. Arsenic ground water contamination in parts of middle Ganga plain, Bihar. Curr. Sci., 97: 753-5.

Singh, S.K., Ghose, A.K., Kumar, A., Kislay, K., Kumar, C., Tiwari, R.R., Parwez, R., Kumar and Imam, M.D. 2014. Ground water arsenic contamination and associated health risk in Bihar, India. Int. J. Environ. Res., 8(1): 49-60.

Tondel, M., Rahman, M., Magnuson, A. et al. 1999. The relationship between arsenic levels in drinking water and the prevalence rate of skin lesions in Bagladesh.Environ Health Perspect, 107: 727-29. 
